JURNAL CEMERLANG: Pengabdian pada Masyarakat ISSN 2654-4741

Vol. 1, No. 1, 2018, 1 - 11

DOI: https://doi.org/10.31540/jpm.v1i1.74

\title{
PELATIHAN ROBOTIK LINE FOLLOWER DAN TEKNOLOGI ARDUINO BAGI GURU MIPA DAN PELAJAR SMA/SMK DI WILAYAH KABUPATEN MUSI RAWAS
}

\author{
Yaspin Yolanda, Wahyu Arini \\ STKIP PGRI Lubuklinggau, Indonesia
}

\begin{abstract}
ABSTRAK
Kegiatan pengabdian kepada masyarakat ini bertujuan untuk (1) mendeskripsikan pelaksanaan pelatihan robotik line follower dan teknologi arduino sehingga meningkatkan pemahaman peserta dan (2) mengukur tingkat ketercapaian pemahaman peserta dalam membuat produk ilmiah robotik Line Follower dan Teknologi Arduino. Adapun sasaran peserta kegiatan pelatihan ini adalah guru-guru MIPA SMA/SMK di wilayah Kabupaten Musi Rawas. Pelatihan ini dilaksanakan dengan metode diskusi dan simulasi. Metode pelaksanaan dalam program pengabdian kepada masyarakat ini terbagi menjadi 3 tahap yaitu Prakegiatan, Pelaksanaan dan Pasca kegiatan. Adapun teknik pengumpulan data berupa kuesioner dan dokumentasi hasil pelatihan yang diberikan setiap akhir pertemuan digunakan untuk perbaikan kualitas pelatihan dan pendampingan yang kami lakukan dan mengukur sejauhmana metode pembelajaran, sumber belajar yang digunakan instruktur bermanfaat bagi peserta, serta komposisi teori dan praktik yang diberikan kepada peserta. Kegiatan Pelatihan Dasar Teknologi Robotik dan Teknologi Arduino menunjukkan bahwa (1) Pelaksanaan pelatihan robotik line follower dan teknologi arduino dilaksanakan dengan cara penyampaian materi dan simulasi pembuatan produk-produk robotik secara berkelompok sehingga dapat meningkatkan pemahaman peserta. dan (2) Tingkat ketercapaian pemahaman peserta adalah sangat baik dalam merangkai komponen, dan mengoperasikan sistem arduino diukur berdasarkan keberhasilan produk Line Follower yang telah dibuat peserta.
\end{abstract}

KEYWORDS

Pelatihan robotik dan Teknologi Arduino,

Tingkat Pemahaman Peserta
ARTICLE HISTORY

Received 10 October 2018

Revised 1 December 2018

Accepted 5 December 2018

CORRESPONDENCE Yaspin Yolanda@yaspinyolanda@ymail.com 


\section{JURNAL CEMERLANG: Pengabdian pada Masyarakat}

ISSN 2654-4741

Vol. 1, No. 1, 2018, $1-11$

DOI: https://doi.org/10.31540/jpm.vli1.74

\section{PENDAHULUAN}

Perguruan tinggi berkewajiban menyelenggarakan penelitian dan pengabdian kepada masyarakat disamping melaksanakan pendidikan sebagaimana diamanahkan oleh Undang undang Nomor 20 Tahun 2003 tentang Sistem Pendidikan Nasional Pasal 20. Sejalan dengan kewajiban tersebut, Undangundang Nomor 12 Tahun 2012 tentang Pendidikan Tinggi Pasal 45 menegaskan bahwa penelitian di perguruan tinggi diarahkan untuk mengembangkan ilmu pengetahuan dan teknologi, serta meningkatkan kesejahteraan masyarakat dan daya saing bangsa. Dalam pasal tersebut juga ditegaskan bahwa pengabdian kepada masyarakat merupakan kegiatan sivitas akademika dalam mengamalkan dan membudayakan ilmu pengetahuan dan teknologi untuk memajukan kesejahteraan umum dan mencerdaskan kehidupan bangsa.

Perkembangan teknologi dewasa ini menuntut setiap individu baik dari kalangan siswa sekolah dasar hingga menengah, guru, mahasiswa, akademisi, praktisi, maupun dari masyarakat umum untuk tanggap dan peka terhadap fenomena/perubahan yang terjadi. Pengamatan secara empiris terhadap perkembangan teknologi saat ini akan menuntut adanya keselarasan antara teoriteori yang dipelajari di sekolah-sekolah dan perguruan tinggi dengan keadaan di lapangan. Dunia kampus selain dapat digunakan sebagai cermin pola berpikir mahasiswa dalam membangun idealisme yang mantap, juga merupakan sarana untuk berkarya dalam menghasilkan ide-ide atau inovasi-inovasi baru dalam bidang teknologi, sehingga mampu menggerakkan perkembangan teknologi di masa datang. Kegiatan seminar dan presentasi ilmiah nasional, pelatihan/workshop, serta pameran teknologi merupakan kegiatan yang efektif untuk menambah gairah pola berpikir dan penalaran mahasiswa terhadap informasi - informasi teknologi.

Yusuf (2016) menjelaskan bahwa kata robot sendiri diperkenalkan ke publik oleh Karel Capek pada saat memainkan RUR (Rossum's Universal Robots), namun awal munculnya robot dapat diketahui dari bangsa Yunani kuno yang membuat patung yang dapat dipindah-pindahkan. Robot adalah sebuah alat 


\section{JURNAL CEMERLANG: Pengabdian pada Masyarakat}

\section{ISSN 2654-4741}

Vol. 1, No. 1, 2018, $1-11$

DOI: https://doi.org/10.31540/jpm.v1i1.74

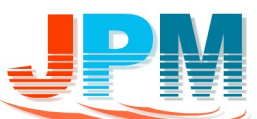

mekanik yang dapat melakukan tugas-tugas fisik, baik menggunakan pengawasan dan kontrol manusia, ataupun menggunakan program yang telah dimasukkan terlebih dulu. Widiastuti (2016) mengatakan bahwa Kegiatan ekstrakulikuler adalah kegiatan yang dilakukan siswa sekolah, di luar jam kegiatan belajar kurikulum utama. Kegiatan ekstrakulikuler merupakan aktivitas yang harus siswa dengan tujuan nenambah kemampuan berfikir dan berkreasi untuk beradaptasi dengan tuntutan siswa saat ini yang harus memiliki wawasan luas dengan memperhatikan proses berpikir dan tingkah laku seseorang bukan hanya pengembangan pengetahuan ilmiah dan teoritis.

Prodi Pendidikan Fisika merupakan bagian keluarga STKIP PGRI Lubuklinggau sebagai salah satu institusi pendidikan harus mampu turut ambil bagian dalam perkembangan teknologi tersebut. Kurikulum berbasis KKNI pendidikan fisika terdapat mata kuliah wajib elektronika dan praktikum eletronika, dan mata kuliah pilihan adalah robotik menjadikan output lulusan S1 Pendidikan fisika ini paham akan elektronika dan mampu menerapkan ilmunya di masyarakat. Menurunnya animo masyarakat untuk memilih program studi ini menjadi tugas utama untuk mendesain program kegiatan masyarakat sekaligus untuk merekrut mahasiswa baru melalui robotik dan arduino.

Kehadiran ekstrakurikuler robotik dan arduino di sekolah khususnya di tiga wilayah kabupaten Musi Rawas Utara, kabupaten Musi Rawas dan kota Lubuklinggau belum semarak kegiatan ekstrakurikuler pramuka di sekolahsekolah baik tingkat SD, SMP dan SMA.

Berdasarkan hasil wawancara kami pada 12 november 2017 di SMK Negeri Rawas Ulu tentang robotik dengan kepala sekolah, bahwa jika ekstrakurikuler robotika diadakan di sekolah maka sangat banyak siswa yang minat bergabung, tetapi kenyataannya sekolah belum memiliki guru yang dapat menjadi pengampu kegiatan ekstrakurikuler robotika. Selain itu sekolah juga tidak memiliki fasilitas pendukung robot kit. Permasalahan utama adalah minimnya SDM yang paham robotik dan arduino dan keterbatasan alat-alat robotik dan arduino belum semaraknya kompetisi-kompetisi robotik dan arduino di tiga 


\section{JURNAL CEMERLANG: Pengabdian pada Masyarakat}

\section{ISSN 2654-4741}

Vol. 1, No. 1, 2018, $1-11$

DOI: https://doi.org/10.31540/jpm.v1i1.74

wilayah tersebut. Prodi Pendidikan Fisika melalui mata kuliah praktikum elektronika telah menghasilkan beberapa produk penelitian robotik yakni mobil line follower, dan produk penelitian arduino yakni kontrol lampu AC dan Relay berbasis arduino, dan kontrol palang pintu kereta api berbasis BASCOM. Sehingga penerapan teknologi robotik dan arduino perlu disosialisasikan melalui kegiatan Pengabdian Masyarakat.

STKIP PGRI Lubuklinggau sebagai kampusnya pendidikan, sebagai pusatnya belajar para siswa-siswa turut ambil bagian dalam mengatasi permasalahan diatas, terlebih lagi bagi mahasiswa S1 Pendidikan Fisika STKIP PGRI Lubuklinggau yang berafiliasi langsung ke mata kuliah elektronika yakni robotik dan arduino sehingga lulusan dan mahasiswanya yang memiliki Life Skill robotik dan arduino bisa menjadi solusi yakni sebagai para pembina ekstrakurikuler robotik dan arduino di sekolah-sekolah baik tingkat SD, SMP maupun SMA.

Berdasarkan permasalahan yang diuraikan di atas, kami yang tergabung dalam tim pengabdian masyarakat bermaksud untuk mensosialisasikan produk hasil penelitian dan penerapannya dalam kegiatan "Pelatihan Robotik Line Follower Dan Teknologi Arduino".

Adapun yang menjadi tujuan diselenggarakannya kegiatan Pelatihan Dasar Teknologi Robotik Dan Arduino Sebagai Kegiatan Ekstrakurikuler Siswa adalah:

1. Mendeskripsikan pelaksanaan pelatihan robotik dan teknologi arduino sehingga meningkatkan pemahaman peserta.

2. Untuk mengukur tingkat ketercapaian pemahaman peserta dalam membuat produk ilmiah robotik Line Follower dan Teknologi Arduino

Adapun sasaran peserta kegiatan pelatihan ini adalah calon pembina ekstrakurikuler yakni guru-guru MIPA dan Pelajar SMA/SMK di Kabupaten Musi Rawas mengirim utusannya maksimal 3 orang. Adapun pola rekrutmen peserta pelatihan dilakukan dengan cara, peserta melakukan registrasi online/manual melalui laman yang telah disiapkan oleh tim pelaksana, melakukan perjanjian secara tertulis tentang hak dan kewajiban peserta. 


\section{JURNAL CEMERLANG: Pengabdian pada Masyarakat}

\section{ISSN 2654-4741}

Vol. 1, No. 1, 2018, $1-11$

DOI: https://doi.org/10.31540/jpm.v1i1.74

\section{MASALAH}

Sehingga Adapun yang menjadi yang menjadi permasalahan dalam kegiatan Pelatihan Dasar Teknologi Robotik dan Teknologi Arduino adalah (1) bagaimanakah Pelaksanaan pelatihan robotik dan teknologi arduino sehingga meningkatkan pemahaman peserta?, (2) bagamanakah tingkat ketercapaian pemahaman peserta dalam membuat produk ilmiah robotik Line Follower dan Teknologi Arduino. Permasalahan yang dialami mitra ini dapat dilihat pada Tabel 1.

Tabel 1. Kondisi fisik, Sosial, Ekonomi dan Lingkungan Mitra

\begin{tabular}{|l|l|}
\hline \multicolumn{1}{|c|}{ Indikator } & \multicolumn{1}{|c|}{ Gambaran Umum } \\
\hline Ekstrakurikuler & $\begin{array}{l}\text { Ekstrakurikuler Robotik sudah menjadi program kerja } \\
\text { sekolah, belum terbentuk karena belum adanya } \\
\text { pelatih sehingga tidak berjalan dengan baik. }\end{array}$ \\
\hline Daya Dukung Sekolah & $\begin{array}{l}\text { Fasilitas Sekolah sangat mendukung untuk } \\
\text { terbentuknya ekstrakurikuler robotik adanya ruang } \\
\text { multimedia dan Laboratorium sains }\end{array}$ \\
\hline $\begin{array}{l}\text { Kegiatan } \\
\text { pendampingan }\end{array}$ & $\begin{array}{l}\text { Lingkungan sekolah terletak di dalam wilayah } \\
\text { lubuklinggau kelurahan Jogoboyo, ditempuh selama } \\
\text { me menit dari STKIP PGRI Lubuklinggau } \\
\text { menggunakan motor dengan kelajuan standar } \\
\text { sehingga memudahkan tim untuk melakukan } \\
\text { pendampingan setelah kegiatan pelatihan. }\end{array}$ \\
\hline
\end{tabular}

\section{METODE}

Kegiatan Pelatihan Dasar Robotik dan Arduino ini dilaksanakan dengan metode pelatihan misalnya diskusi, penugasan dan praktik atau simulasi. Adapun teknik pengumpulan data berupa kuisioner diberikan setiap akhir pertemuan digunakan untuk perbaikan kualitas pelatihan, simulasi dan pendampingan yang kami lakukan dan mengukur sejauhmana metode pembelajaran, sumber belajar yang digunakan instruktur bermanfaat bagi peserta, serta komposisi teori dan praktik yang diberikan kepada peserta. Kemudian dianalisis secara deskriptif seperti pada tabel 2.

Metode pelaksanaan dalam program pengabdian kepada masyarakat ini terbagi menjadi 3 tahap yaitu sebagai berikut: 


\section{JURNAL CEMERLANG: Pengabdian pada Masyarakat}

ISSN 2654-4741

Vol. 1, No. 1, 2018, $1-11$

DOI: https://doi.org/10.31540/jpm.v1i1.74

\section{Prakegiatan}

Agar pelaksanaan berjalan dengan baik dan maksimal, hal-hal yang kami lakukan pada tahap ini yaitu sebagai berikut:

1. Rapat strategi pelaksanaan, yang dilaksanakan sesuai jadual yang telah dibuat yakni membuat struktur organisasi tim pelaksana, membahas pembagian tugas masing-masing anggota dan membuat proposal.

2. Survei tempat pelaksanaan, berdasarkan hasil observasi dan wawancara pengguna, sudah ada beberapa sekolah yang siap mengadakan ekstrakurikuler robotik dan menyiapkan calon-calon anggotanya serta siap bekerjasama secara tertulis dengan tim pelaksana.

3. Pembelian alat dan bahan, ketersediaan alat dan bahan kami bekerjasama dengan toko elektronik varco indah, Robotik online shop, dan produk-produk hasil penelitian mahasiswa prodi pendidikan fisika yakni 3 set robotik mobil line follower, 1 set kontrol lampu AC berbasis arduino, 1 set kontrol relay berbasis arduino.

4. Sosialisasi program kepada masyarakat (Pengguna). Kegiatan mensosialisasikan berupa program Robotik Goes To School, bekerjasama dengan media cetak Linggau Pos dengan membuat iklan, dan peliputan kegiatan dari awal sampai akhir pelaksanaan kegiatan pengabdian masyarakat ini.

5. Registrasi Peserta, kegiatan registrasi sangat perlu kami lakukan untuk melihat sejauhmana animo masyarakat(pengguna) berpatisipasi dalam pelatihan ini. Registrasi peserta dilaksanakan secara online dan manual.

\section{Pelaksanaan Kegiatan}

Dalam merealisasikan program pengabdian masyarakat, kami menerapkan beberapa metode, diantaranya:

\section{Waktu dan tempat pelaksanaan}

Pelatihan akan dilaksanakan dalam waktu 4 bulan yang di mulai bulan di danainya proposal ini (Oktober 2017 s.d. Januari 2018). Pelatihan 


\section{JURNAL CEMERLANG: Pengabdian pada Masyarakat}

ISSN 2654-4741

Vol. 1, No. 1, 2018, $1-11$

DOI: https://doi.org/10.31540/jpm.v1i1.74

dilaksanakan setiap akhir pekan dengan durasi pelatihan 180 menit setiap pertemuannya. Demi efektivitasnya kegiatan pelatihan ini, tim pelaksana membatasi peserta yang mengikuti pelatihan adalah 100 peserta.

\section{Metode pelaksanaan}

a. Penyampaian Materi, Kami menyampaikan materi kepada peserta dengan bahasa yang mudah dipahami sehingga peserta bisa mengerti. Penyampaian materi melalui media power point sehingga lebih menarik, dan mendemonstrasikan media, pemutaran video pembelajaran. Selain itu kami juga memberikan modul pelatihan kepada peserta sebagai pedoman.

b. Simulasi, Memberikan simulasi tentang produk-produk robotik dan arduino yang akan dibuat. Selanjutnya peserta mengaplikasikannya secara langsung dengan menggunakan alat dan bahan yang telah kami persiapkan.

\section{Pasca kegiatan}

Tahap pasca kegiatan adalah tahap akhir dari program pengabdian kepada masyarakat. Dalam tahap ini ada beberapa hal yang dilakukan, yaitu :

1. Pembentukan ekstrakurikuler Robotik di sekolah secara formal.

2. Monitoring dan Pendampingan dengan di Laboratorium Fisika STKIP PGRI Lubuklinggau. Pendampingan sangat perlu kami lakukan sebagai wadah peserta dan siswa yang ingin memahami lebih jauh bimbel ini, yang akan dikelola oleh Tim Pelaksana.

3. Pembuatan Laporan, Laporan pelaksanaan Pengabdian Masyarakat akan dibuat selama kegiatan ini berlangsung (Desember 2017 s.d. Maret 2018).

Tabel 2. Teknik Pengumpulan dan Analisa Data

\begin{tabular}{|l|l|l|}
\hline Variabel & Teknik Data & Responden \\
\hline Bentuk Program & Kuisioner dan Dokumentasi dan & Peserta \\
1. Pelatihan & dianalisa secara deskriptif & pelatihan \\
2. Simulasi & & \\
3. Pendampingan & & \\
\hline
\end{tabular}




\section{JURNAL CEMERLANG: Pengabdian pada Masyarakat}

ISSN 2654-4741

Vol. 1, No. 1, 2018, $1-11$

DOI: https://doi.org/10.31540/jpm.v1i1.74

\section{PEMBAHASAN}

Kegiatan Pelatihan Dasar Teknologi Robotik dan Teknologi Arduino menunjukkan bahwa (1) Pelaksanaan pelatihan robotik line follower dan teknologi arduino dilaksanakan dengan cara penyampaian materi dan simulasi pembuatan produk-produk robotik secara berkelompok sehingga dapat meningkatkan pemahaman peserta. Dan (2) Tingkat ketercapaian pemahaman peserta adalah sangat baik dalam merangkai komponen, dan mengoperasikan sistem arduino diukur berdasarkan keberhasilan produk Line Follower yang telah dibuat peserta.

Kegiatan Pelatihan Dasar Teknologi Robotik Line Follower dan Teknologi Arduino ini dilaksanakan selama satu minggu dari tanggal 20-27 Desember 2017 di SMK Rawas Ulu. Adapun narasumber dari tim dosen pelaksana. Untuk lebih jelasnya dapat dilihat pada tabel 2. Pemberian materi pelatihan selam tujuh hari ini dibantu oleh tiga pembicara yakni Yaspin Yolanda, M.Pd.Si yang memberikan materi tentang teknologi protoboard dan simulasi teknik menyolder dan materi kedua yakni simulasi rancang bangun Line Follower. Pembicara kedua Wahyu Arini, M.Pd.Si memberikan materi pada pertemuan pertama tentang Pengetahuan Komponen Dasar Elektronika dan Pengetahuan Dasar Robotik dan Arduino, hari kedua memberikan materi tentang Managemen Ektrakurikuler Robotik dan Kurikulum Robotik bagi Pembina Ekstrakurikuler. Pembicara ketiga Yaspin Yolanda, M.Pd.Si., memberikan materi tentang Pengetahuan Dasar Pemograman Arduino, Simulasi rancang bangun Rangkaian Power Supply dan Simulasi rancang bangun kontrol lampu AC berbasis Arduino. Pelatihan yang dihadiri 100 peserta lebih dari berbagai sekolah di wilayah Dinas Pendidikan Kabupaten Musi Rawas ini dimulai dari pukul 08.00 s.d 17.00 WIB dibuka langsung oleh Bupati Musi Rawas yakni Bapak Drs. H. Syarief Hidayat, MM.

Wijaya (2013) menjabarkan bahwa alat dan bahan yang digunakan dalam pembuatan mobil Line Follower sebagai pusat pengontrol adalah mikrokontroler ATMEGA 16. Dengan menggunakan DI-Smart AVR System sebagai kit minimum system. PORT-PORT yang digunakan untuk Robot Pengantar Makanan line follower yaitu PORTD.0 - PORTD.7, VCC dan GND sebagai input sensor 
JURNAL CEMERLANG: Pengabdian pada Masyarakat ISSN 2654-4741

Vol. 1, No. 1, 2018, $1-11$

DOI: https://doi.org/10.31540/jpm.vli1.74

proximity photodioda, PORTB.0 - PORTB.1 sebagai output Relay, PORTB.4, VCC,GND sebagai output modul suara ISD17240, PORTA.0 -PORTA.1, VCC sebagai input PushButton, PORTC.0 - PORTC.3 sebagai output Motor Driver 4A.

Pelatihan ini dilaksanakan selama tujuh hari dari tanggal 20 s.d. 27 Desember 2018. Bentuk pelatihan berupa penyampaian materi dan simulasi pembuatan produk robotik. Siswa diajak memahami serta mencoba bagaimana sebuah rangkaian elektronika sederhana dapat bekerja dengan memberikan penjelasan merakit rangkaian tersebut. Siswa diajak untuk memahami sebuah blok diagram sederhana dengan cara memperagakan sebuah rangkaian sederhana Line Follower dan menjelaskan cara kerjanya dengan memberikan permisalan pada kerja robot. Selain itu siswa diajak bereksperimen untuk merakit sebuah robot pengikut garis.

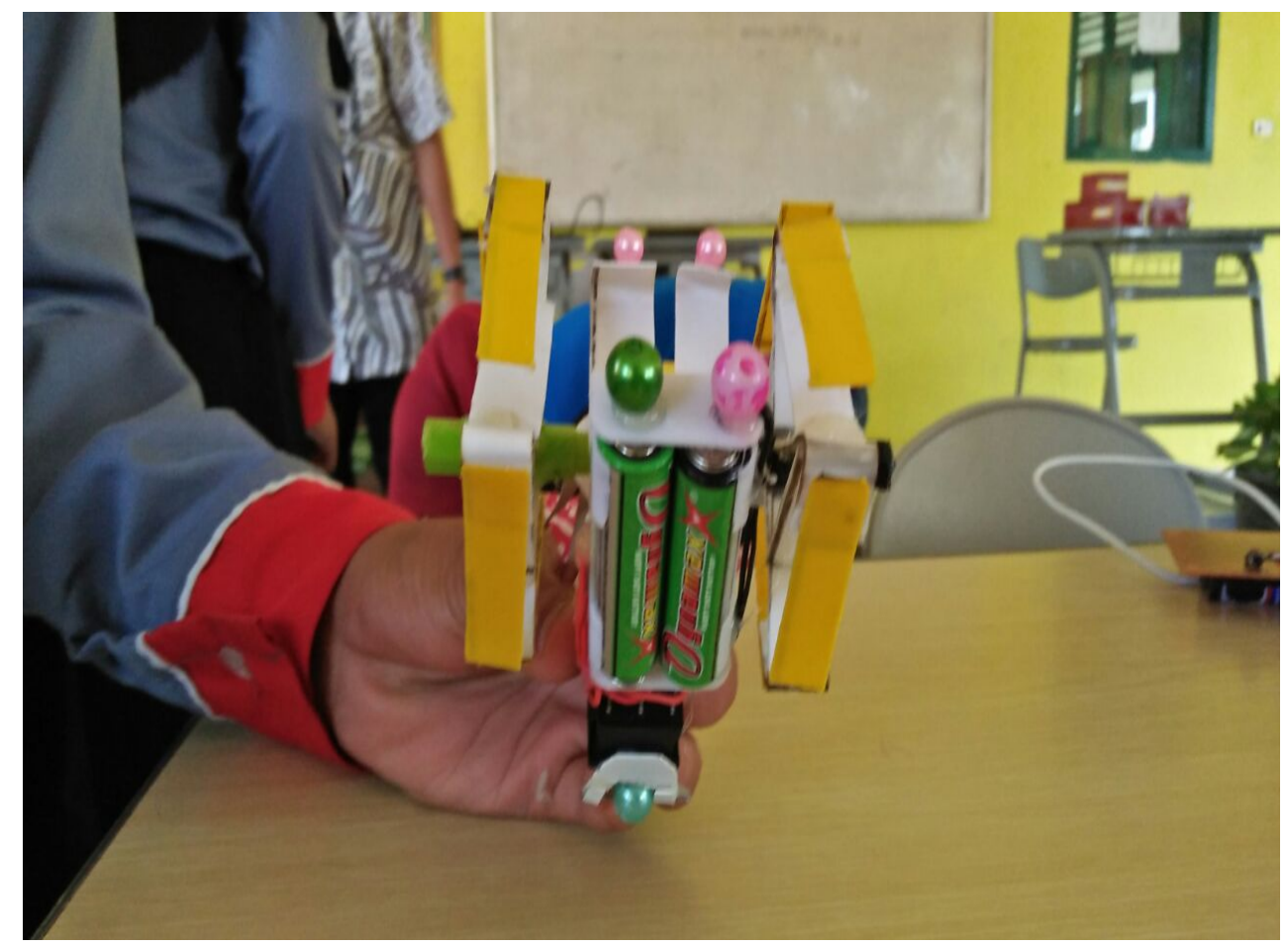

Gambar 1. Robot Hasil Karya Peserta 
JURNAL CEMERLANG: Pengabdian pada Masyarakat ISSN 2654-4741

Vol. 1, No. 1, 2018, $1-11$

DOI: https://doi.org/10.31540/jpm.v1i1.74

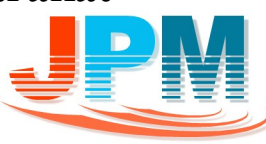

Tabel 3. Struktur Program Pelatihan Robotik Dan Teknologi Arduino

\begin{tabular}{|c|c|c|c|c|}
\hline No & Materi & Pembicara & $\begin{array}{l}\text { Alokasi } \\
\text { Waktu }\end{array}$ & Pembahasan \\
\hline 1 & \begin{tabular}{lr|} 
Simulasi & rancang \\
bangun & line \\
Follower & \\
\end{tabular} & \multirow{2}{*}{$\begin{array}{l}\text { Yaspin } \\
\text { Yolanda, } \\
\text { M.Pd.Si. }\end{array}$} & $8 \mathrm{Jam}$ & $\begin{array}{l}\text { Peserta memcoba merakit } \\
\text { komponen Line Follower } \\
\text { ke papan PCB dan } \\
\text { melakukan teknik } \\
\text { menyolder dan melakukan } \\
\text { uji coba alat. }\end{array}$ \\
\hline 2 & $\begin{array}{lr}\text { Teknologi, } & \\
\text { protoboard } & \text { dan } \\
\text { simulasi } & \text { teknik } \\
\text { menyolder } & \end{array}$ & & $8 \mathrm{Jam}$ & $\begin{array}{l}\text { Peserta mempelajari papan } \\
\text { PCB dan melakukan teknik } \\
\text { menyolder yang benar } \\
\text { menggunakan } \\
\text { sebagai medianya }\end{array}$ \\
\hline 3 & $\begin{array}{l}\text { Pengetahuan } \\
\text { Komponen Dasar } \\
\text { Elektronika }\end{array}$ & \multirow{4}{*}{$\begin{array}{l}\text { Wahyu } \\
\text { Arini, } \\
\text { M.Pd.Si. }\end{array}$} & $4 \mathrm{Jam}$ & $\begin{array}{l}\text { Peserta mempelajari fungsi } \\
\text { komponen-komponen } \\
\text { seperti sensor ATMEGA, } \\
\text { led, resistor, capasitor dan } \\
\text { transistor }\end{array}$ \\
\hline 4 & $\begin{array}{l}\text { Pengetahuan } \\
\text { Dasar Robotik dan } \\
\text { Arduino }\end{array}$ & & $4 \mathrm{Jam}$ & $\begin{array}{l}\text { Peserta mempelajari } \\
\text { sejarah perkembangan ilmu } \\
\text { teknologi arduino dalam } \\
\text { peranan revolusi industri }\end{array}$ \\
\hline 5 & $\begin{array}{l}\text { Kurikulum } \\
\text { Robotik bagi } \\
\text { Pembina } \\
\text { Ekstrakurikuler }\end{array}$ & & $4 \mathrm{Jam}$ & $\begin{array}{l}\text { Pembina } \\
\text { mempelajari kurikulum } \\
\text { robotik dan standarisasi } \\
\text { perlombaan robotik }\end{array}$ \\
\hline 6 & $\begin{array}{l}\text { Managemen } \\
\text { Ektrakurikuler } \\
\text { Robotik }\end{array}$ & & $4 \mathrm{Jam}$ & $\begin{array}{lr}\text { Peserta } & \text { diajarkan } \\
\text { managemen } & \text { rapat, } \\
\text { membuat program kerja } \\
\text { dan pembagian tugas } \\
\text { organisasi }\end{array}$ \\
\hline 7 & $\begin{array}{l}\text { Pengetahuan } \\
\text { Dasar } \\
\text { Pemograman } \\
\text { Arduino }\end{array}$ & \multirow{3}{*}{$\begin{array}{l}\text { Yaspin } \\
\text { Yolanda, } \\
\text { M.Pd.Si. }\end{array}$} & $4 \mathrm{Jam}$ & $\begin{array}{l}\text { Peserta mempelajari dasar- } \\
\text { dasar pemograman arduino }\end{array}$ \\
\hline 8 & $\begin{array}{l}\text { Simulasi rancang } \\
\text { bangun Rangkaian } \\
\text { Power Supply }\end{array}$ & & $4 \mathrm{Jam}$ & $\begin{array}{l}\text { Peserta membuat rangkaian } \\
\text { power supply } 3-12 \text { Volt } \\
\text { dengan bimbingan tentor }\end{array}$ \\
\hline 9 & \begin{tabular}{lr|} 
Simulasi & rancang \\
bangun & kontrol \\
lampu & $\mathrm{AC}$ \\
berbasis & Arduino
\end{tabular} & & $8 \mathrm{Jam}$ & $\begin{array}{l}\text { Peserta membuat rangkaian } \\
\text { kontrol lampu AC } \\
\text { menggunakan arduino }\end{array}$ \\
\hline \multicolumn{3}{|c|}{ Jumlah Jam } & 48 Jam & \\
\hline
\end{tabular}

https://ojs.stkippgri-lubuklinggau.ac.id/index.php/JPM 


\section{JURNAL CEMERLANG: Pengabdian pada Masyarakat}

\section{ISSN 2654-4741}

Vol. 1, No. 1, 2018, $1-11$

DOI: https://doi.org/10.31540/jpm.v1i1.74

\section{SIMPULAN}

Kegiatan Pelatihan Dasar Teknologi Robotik dan Teknologi Arduino menunjukkan bahwa:

1. Pelaksanaan pelatihan robotik dan teknologi arduino dilaksankan dengan cara penyampaian materi dan simulasi pembuatan produk-produk robotik secara berkelompok sehingga dapat meningkatkan pemahaman peserta.

2. Tingkat ketercapaian pemahaman peserta adalah sangat baik dalam membuat produk ilmiah robotik Line Follower dan Teknologi Arduino diukur berdasarkan keberhasilan produk Line Follower yang telah dibuat peserta.

\section{DAFTAR PUSTAKA}

Daisy A.N Janis, Dkk. (2014), Rancang Bangun Robot Pengantar Makanan Line follower. e-journal Teknik Elektro dan Komputer (2014), ISSN: 2301-8402 1. Jurusan Teknik Elektro-FT, UNSRAT.

Widiastuti, Ika. Dkk. (2016), Peningkatan Kreativitas Siswa SD Negeri Karangrejo 2 Melalui Ekstrakurikuler Robotika. Prosiding Seminar Hasil Penelitian dan Pengabdian Masyarakat Dana BOPTN Tahun 2016, ISBN : 978602-14917-3-7. Jurusan Teknologi Informasi, Politeknik Negeri jember.

Wijaya. Husain Arief. (2013), Evaluasi implementasi pelatihan Robotika Menggunakan Arduino di SMK Negeri 1 Sedayu Bantul. Universitas Negeri Yogyakarta.

Yusuf, M. Dkk. (2016). Implementasi Robot Line Follower Penyiram Tanaman OtomatisMenggunakan Metode Proportional-Integral-Derivative Controller (Pid. semanTIK, Vol.2, No.1, Jan-Jun 2016, pp. 111-124. ISSN : 2502-8928 (Online). Jurusan Teknik Informatika, Fakultas Teknik, Universitas Halu Oleo, Kendari 